UDC 339.13

http://doi.org/10.21272/mmi.2018.4-18

JEL Classification: L21, M21, R58

Ladislav Mura,

D.Sc., Associate Professor, Pan-European University in Bratislava, Slovakia

Martina Marchevska,

D.Sc., University of Presov, Slovakia

Mariana Dubravska,

D.Sc., University of Presov, Slovakia

\title{
SLOVAK RETAIL BUSINESS ACROSS PANEL REGRESSION MODEL
}

Abstract. The business sector is directly linked to many other social and economic indicators of the settlement, region and the state. Especially the retail trade is influenced by the consumption of households that directly affects the regional development. This present paper deals with the essence of the understanding of the retail industry as well as its impact on regional development in the Slovak Republic on the basis of the presented analyses of selected macroeconomic indicators in the SR. Addressing the issue was preceded by the systematic collection of the scientific literature of the studied issue in order to comprehensively assess the individual variables. The main purpose of the research is to verify statistical significance between the registered number of employees in the retail sector and its impact on the regional development with an accent on the chosen macroeconomic indicator, as well as evaluate the results gained by verification of the model. The focus of the survey is on the Slovak retail sector. The retail sector of Slovakia is analysed on the basis of macroeconomic data. Setting hypotheses were essential to conduct the analysis. We suggest verifying the hypotheses I and II, which concern according to two variables. To verify the hypotheses, annual data from the time interval of 2000 - 2010 was used. Based on the indicators of hypotheses evaluation, a recorded number of employees in retail trade and the ratio of employed in retail business as a part of the total employment in the region had been applied. Methodological tools of the research methods were standard deviations (t-statistics, $p$-values) have been estimated by Driscoll-Krayy estimator and Ordinary Least Squares Method. This paper presents the results of an empirical analysis and the statistical findings are expressed by statistical software Stata. The analysis of macroeconomic correlation detected the direct relationship between the number of employees in the retail sector and the regional GDP.

Keywords: gross domestic product; regional development; regression model; retail business; Slovakia.

Introduction. The business sector is a basis of the functioning economy and forms a substantial part of the GDP. It is present in different regions of the country. By conducting business and successful implementation of activities contribute to achieving success on the market. It is, therefore, the interest of all the stakeholders to create favourable conditions for the development of these activities, since these enterprises generate GDP, introduce innovations and contribute to regional development. More than twothirds of business activities are retail operations i.e. trade directed to smaller units. Several remarkable changes have been introduced in the retail sector over the past period that requires deeper analysis. It can help determine the direction of the retail business and identify the gaps in the sector. This is the reason we find important to address this issue.

The concentration of retail business can be considered as a primary issue of regional development in Slovakia. Regional development is determined by the development of entrepreneurial activities in the primary, secondary and tertiary sector of the economy. This is the reason we find important to address this issue. The main goal of this paper is to verify statistical signification of the relationship between the recorded number of employees in retail and its impact on the regional development with accent on chosen macroeconomic indicator and to evaluate results gained by verification of model. To verify the hypotheses, annual data from the time interval of 2000 - 2010 was used. Standard deviations (t-statistics, p-values)

Cite as: Mura, L., Marchevska, M., \& Dubravska, M. (2018). Slovak Retail Business Across Panel Regression Model. Marketing and Management of Innovations, 4, 203-211. http://doi.org/10.21272/mmi.2018.4-18 
have been estimated by Driscoll-Krayy estimator and Ordinary Least Squares Method. Statistical findings are expressed by statistical software- Stata. The presented paper has the following structure: introduction, literature review, aim and methodology part. In the Introduction chapter, we emphasise the significance of the issue and its importance to related areas. The literary review provides a theoretical elaboration of the researched issue based on domestic and foreign literature and relevant opinion of experts and their scientific work published in scientific databases. Further part of the article focuses on the results obtained and the summary of the analysis conducted. The last chapter of the article is dedicated to the summary of the research results and conclusion.

Literature review. Based on the retail business searching trend of substitution of traditional stores by larger stores such as hypermarkets can be defined. It is a process of modernization of retail business. Many scientists search regularities of this segment and by its impact predict future collocation of the retail business and employment in the sector. Retail companies account primarily to market share and not the availability of the goods for customers (Gburová and Marchevska, 2016; Peracek, Kocisova, Mucha 2017).

Retailing and consumption represent potentially one of the most important and one of the most difficult fields of study (Križan, 2009). Total economic performance of the country depends on individual sectors performance and on the interaction among them. Most firms produce not only final products but also intermediate products for other firms. It results in interaction between firms and sectors while production and employment in one sector directly or indirectly depend on production and employment in another one (Labaj, 2013). There exist a dominance of business subjects in Slovak retail business in towns while the share in the rural villages is much lower. The most significant development of this sector has been achieved in 2010. It corresponds to the upward trend of this sector and with the entire society trend in transforming economies (Bilkova and Krizan, 2013; Korcsmáros, 2018).

Slovak consumers are influenced by several factors during decision making to purchase goods or services (Štefko et al., 2015). Based on consumer preferences we can summarize several conclusions. The consumer is the most important factor determining the location of the retail store. A recent study shows that $41,6 \%$ of the Slovak consumers shop daily, while $37,4 \%$ do their shopping several times a week. This makes a good reason to study the consumer behaviour and localization of retail outlets (Lauko et al., 2008). The shopping behaviour of young consumers analysed by the indicator of shopping frequency does not deter significantly from the shopping behaviour of other consumers. An irregular growth of young customer segment can be identified, as they have irregular financial income. Most often they do shopping several times a week, while this frequency presents almost half of the shopping activity (Križan et al., 2017). The increasing informatization of the social influences not only the quality of life but also the habits and needs of customers. We can experience a change in interpersonal as well as marketing communication. The consumers have become resistant to conventional tools of communication mix while favouring the communication on social networking sites. This shift in communication channels has become a challenge for businesses (Majerová et al., 2013). Scientific literature focusing on consumer behaviour and price strategies is represented by Bačík et al., 2014; Bobáková and Hečková, 2007; Lesáková at al., 2013; Lieskovská et al, 2016; Musová et al., 2016; Seres Huszárik and Dobai Korcsmáros,2013; Moravcikova et al, 2017.

The key issue within the framework of understanding of the retail business importance has become localization (Spilkova, 2016). Localization of stores is a process to select the most appropriate location (region) for the concrete socio-economic activity. Each region has certain resources and each activity is characterized by certain needs (Lynch et al., 2017). In recent years a greater emphasis has been put on regional and local development strategies (Benešová et al., 2018). Clusters have become popular because they represent efficient structures to increase competitiveness, productivity and innovation in particular regions" Nemcová (2004). Chain stores and business representatives decide about the market potential, logistic links, transport conditions, which can influence the living standard of citizens (Gródek- 
Szostak, and Nesterak, Mazurek, 2017; Hadad, and Cantaragiu, 2017). While some chains prefer the localization of their stores close to their competitors with a similar product mix, others try to enter the market first (Tvaronavičienè et al., 2018). It happens very often that stores are located into towns characterised by dynamic change and the growth of market potential e.g. building of new flats is planned (Buček et al., 2010; Anyakoha, 2018). According to Grewal D. et al. (2016), the retail business can be understood as brick-and-mortar stores, which allow customers to touch and interact with products, being connected with other customers, and receive direct feedback from sales staff. Catalogues help customers to find detailed product information. In addition to detailed product information, online stores also grant direct access to other customers' reviews of products or services. Mobile phones provide a new form of communication with the customer, that enable salespeople to promote and sell their products and services indirectly to customers (Samašonok et al., 2016). The best location for a retail unit is an area with optimal sources for the socio-economic activities. Therefore, we can agree with the opinion that localization is the most important aspect of the research (Slach et al., 2013; Kotulič et al., 2017). Location of the store increases the ability to absorb larger operational capacities that involve economic advantages:

- by increasing operational capacity we can achieve increased possibilities for sales, the efficient division of labour and better organization of work,

- by increasing investment and operational costs of the product portfolio (production costs), the unit costs will decrease,

- large retail units have successful assumptions for own technical development (Kita et al.2017).

According to Lagakos (2016), many macroeconomists argue that developing countries show a low productivity rate, as they find difficult to adopt modern technological achievements. In the retail sector, these countries choose technologies requiring low productivity of work. His theory says that the adoption of modern retail technologies is optimal if widespread use of consumer durables (e. g. cars) can be recognized. The low income of households determines the low number of consumer durables per household. The theory emphasizes, that policies increasing retail productivity do not necessarily increase welfare. The scientific literature focusing on the retail sector is mostly an economic one (Buček et al., 2010; Tvrdoň et al., 2015) and others.

Methodology. The main objective of this paper is to verify statistical significance between the registered number of employees in the retail sector and its impact on the regional development with an accent on the chosen macroeconomic indicator, as well as evaluate the results gained by verification of the model.

To achieve the main objectives, we set the following partial objectives:

- analyze employment in retail business and its relation to the regional GDP per capita within selfgoverning regions of Slovakia,

- analyse the share of employment in retail network compared to total employment, and regional GDP per capita within the self-governing regions of Slovakia,

- to analyse the statistical significance of the relationship by implementing the panel regression model; it is followed by the conclusion and recommendations for the chosen segment.

The Analysis of Measuring Macroeconomic Correlation. To verify the hypotheses, annual data from the time interval of 2000-2010 was used. The impact of employment on the chosen macroeconomic indicator has been evaluated by several indicators. The necessary data has been gained from secondary sources of the Statistical Office of the Slovak Republic. It was processed and evaluated by statistical software PASW Statistics 18 (former SPSS Statistics). The total number of observations per variable is on a scale of 72-80. The verification of development (i. change) shows variables on a scale of 64-72. Standard deviations (t-statistics, $p$-values) have been estimated by Driscoll-Krayy estimator and Ordinary Least Squares Method. Statistical findings are expressed by statistical software- Stata.

Instability of variables is the major problem from the methodological aspect according to time series. 
If the time series is not stationary or cointegrated and there are inputs for the regression analysis, the results may be false. If both variables show a trend in the determined time interval, we can find a strong relationship between the variables. Therefore, we analyse the results of the time series. If they are stationary, we can trust the regression models. If they are not, it is questionable whether we can trust them. To determine the state of the variables we used the Panel Test - Harris \& Tzavalis test. Results are presented in Table 1.

Table 1 - Verification of (non) stationary level variables

\begin{tabular}{|l|c|c|c|c|}
\hline & \multirow{2}{*}{$\mathrm{N}$} & \multirow{2}{*}{ trend? } & \multicolumn{2}{|c|}{ Harris-Tzavalis } \\
\cline { 4 - 5 } & & & Z statistics & p-value \\
\hline Recorded number of employees & 80 & yes & $-2,767$ & 0,003 \\
\hline Number of representative companies & 80 & yes & $-0,581$ & 0,281 \\
\hline Sales area & 80 & yes & $-1,517$ & 0,065 \\
\hline Storage area & 80 & yes & 1,931 & 0,973 \\
\hline Sales and storage area together & 80 & yes & 0,294 & 0,616 \\
\hline The ratio of employment in retail trade & 80 & no & $-1,437$ & 0,075 \\
\hline GDP adjusted to price index & 72 & yes & $-1,186$ & 0,118 \\
\hline $\begin{array}{l}\text { Sales for own and retail rales modified upon } \\
\text { price index }\end{array}$ & 80 & yes & $-2,221$ & 0,013 \\
\hline Sales area as a part of the total area & 80 & yes & $-1,755$ & 0,040 \\
\hline
\end{tabular}

Sources: Authors' results, based on the Statistical Office of the Slovak Republic, 2017

The results of the analysis show, that the following variables are stationary (related or not related to deterministic trend):

- the recorded number of employees in retail trade (related to the trend);

- sales area (related to the trend);

- the employment ratio of retail trade as a part of total employment in the region (without trend);

- sales (adjusted by price index and trend);

- the sales area as a part of the total area (without trend), (Hatrák, 2007).

Panel data regressions were used to verify the hypotheses, while fixed effects are considered (no random selection of regions was applied). The following assumptions had been verified:

1. Heteroskedasticity of residues (Wald test).

2. Dependence of residues between the panels (Pesaran test).

3. Autocorrelation of residues (LM test), (De Wachter S. et al., 2007).

Based on the indicators of hypotheses evaluation, a recorded number of employees in retail trade and the ratio of employed in retail business as a part of the total employment in the region had been applied. This way it is possible to gain information either about the importance of retail trade in the country or about the fact, whether the employment growth in retail trade results in the increase of the total economic production. However, the employment rate may rise, the total number of employees in the retail sector may decrease. Originally, the GDP per capita should have been used in the region, but the nominal GDP increase might happen due to the price increase and not because of production growth. In this situation, we cannot talk about an economic growth. To make GDP real, deflator, the consumer price index or price index of industrial goods and services are used. Therefore, the GDP was adjusted to the consumer price index (EUROSTAT database).

We suggest verifying the hypotheses I and II. These are formulated as the following:

1. There is no statistically significant linear relationship between the recorded number of employees in retail and the regional GDP per capita (adjusted to price index). 
2. There is no statistically significant linear relationship between the share of employment in a retail network to the total employment and the regional GDP per capita (adjusted to price index).

Results and discussion. According to regression statistics and statistical testing of hypotheses, we have decided to continue in the linear relationship (Tables 1 and 2) to check statistical signification in case of Hypotheses I and II.

Table 2 - Results of regression statistics and its statistical testing for Hypothesis I

\begin{tabular}{|l|c|c|c|c|}
\hline & Linear & Exponential & Power & Logarithmic \\
\hline Confidence value R & 0,882278 & 0,738105 & 0,654575 & 0,756828 \\
\hline $\begin{array}{l}\text { Corrected coefficient of } \\
\text { determinant }\end{array}$ & 0,880572 & 0,734309 & 0,649569 & 0,753304 \\
\hline T calculated & 22,74045 & 13,94504 & 11,43477 & 14,6536 \\
\hline F table (quantum of & 517,1281 & 194,4643 & 130,7539 & 214,7502 \\
\hline $\begin{array}{l}\text { T table (2,648977 } \\
\text { Student Distribution) }\end{array}$ & 2,648977 & 2,648977 & 2,648977 \\
\hline F table (critical value) & 7,017078 & 7,017078 & 7,017078 & 7,017078 \\
\hline Number of comparisons & 71 & 71 & 71 & 71 \\
\hline
\end{tabular}

Sources: Authors' results

Results of regression analysis for Hypothesis I have shown, that Confidence value $\mathrm{R}$ is the most important from the point of view of testing (71), which is why we will get linear values for the following methods. Results of regression analysis and the statistical test results for Hypothesis II are presented in Table 3.

Table 3 - Results of regression statistics and statistical testing for Hypothesis II

\begin{tabular}{|l|c|c|c|c|}
\hline & Linear & Exponential & Power & Logarithmic \\
\hline Confidence value R & 0,847718 & 0,723887 & 0,57668 & 0,651731 \\
\hline $\begin{array}{l}\text { Corrected coefficient of } \\
\text { determinant }\end{array}$ & 0,845543 & 0,719885 & 0,570545 & 0,646683 \\
\hline T calculated & 19,74016 & 13,44981 & 9,695226 & 11,36321 \\
\hline F calculated & 389,674 & 180,8973 & 93,99741 & 129,1226 \\
\hline $\begin{array}{l}\text { T table (quantum of } \\
\text { Student Distribution) }\end{array}$ & 2,648977 & 2,648977 & 2,648977 & 2,648977 \\
\hline F table (critical value) & 7,017078 & 7,017078 & 7,017078 & 7,017078 \\
\hline Number of comparisons & 71 & 71 & 71 & 71 \\
\hline
\end{tabular}

Sources: Authors' results

Hypotheses 1 and 2 have been verified by the following panel regression model:

$$
\text { hdpadj } i, t=\alpha i+\beta 1 z a m i, t+\beta 2 p z i, t+\beta 3 r o k+u i t
$$

where variables: zam (recorded number of employees) and pz (employment ratio of retail trade as a part of total employment in the region) are variables considered to be stationary, while hdpadj (gross domestic product per inhabitant considering price indices) are not.

The results of testing Hypotheses 1,2 and information about testing methods is provided in Table 4. Presence of the autocorrelation of residues is verified by the LM test. The p-value at 0.296 means, that Hypothesis 0 cannot be rejected because of the absence of first-order correlation. It can be assumed, that there is no autocorrelation in residues and the results of this model will be considered as meaningful. 
Table 4 - Results of a) and b) hypotheses testing in panel regression

\begin{tabular}{|l|c|c|c|c|}
\hline \multicolumn{1}{|c|}{$\mathrm{N}$} & 72 & a). and b). & group \\
\hline & coefficient & Stand, error & T-statistics & p-value \\
\hline $\begin{array}{l}\text { Recorded number of employees in } \\
\text { the retail network }\end{array}$ & 0,83 & 0,09 & 9,11 & 0,00 \\
\hline $\begin{array}{l}\text { Employment ratio of retail trade as } \\
\text { a part of total employment }\end{array}$ & $-128233,30$ & 24601,75 & $-5,21$ & 0,00 \\
\hline Year & 362,99 & 49,28 & 7,37 & 0,00 \\
\hline Constant & $-718860,70$ & 98404,03 & $-7,31$ & 0,00 \\
\hline R2 edited (by OLS estimation) & \multicolumn{4}{|c|}{$08,45 \%$} \\
\hline Wald test & \multicolumn{4}{|c|}{0,00} \\
\hline Pesaran test & \multicolumn{4}{|c|}{0,296} \\
\hline LM test & \multicolumn{4}{|c|}{} \\
\hline
\end{tabular}

Sources: Authors' results

The assumption about homoskedasticity of residuals and spatial irregularity of residuals was broken. Therefore, statistical deviations (t-statistics and $p$-value) in regression have been estimated by applying Driscoll - Kraay estimator and Ordinary Least Squares method.

Conclusion. All variables in Table 4 are statistically significant as it is clear from low p-values in relevant columns. Hypothesis 0 may be rejected in favour of the alternative hypothesis. Hypothesis 0 means that the regression coefficient is statistically equal to zero. In the case of the alternative hypothesis, it is statistically different from zero. If the regression coefficient equals to zero, there is no correlation between the variables. If it is different from zero, there is a correlation between the variables. The model verification detected statistical significance of the parameter recorded number of employees in the retail network ( $0,00 p$-value), employment ratio of retail trade as a part of total employment ( $0,00 p$-value). Based on these results, Hypothesis I and II can be rejected. It is important to remind that both hypotheses have been verified by one regression. If there was a correlation between employment and GDP per inhabitant, the ratio of employment would be taken into account. If there was a correlation between the ratio of employment and the GDP per capita, employment would be taken into account. Achieved findings may be summarized as the following:

Hypothesis 1. A statistically significant linear relationship exists between the recorded number of employees in the retail network and regional GDP per capita. This relationship is direct. If there is higher employment in retail trade, the GDP per capita is higher as well.

Hypothesis 2. There is a statistically significant linear relationship between the ratio of employment in the retail network and regional GDP per capita (adjusted to price index). This relationship is an indirect one. If there is a higher share of employment in retail trade, the GDP per capita is lower.

Higher employment in retail trade shows higher GDP per capita, but not in the case, when the employment increased to detriment of employment in other sectors. Hicks and Wilburn (2001) examined the retail sector in 55 regions of West Virginia in the time interval of 1989-1998. The recursive model evaluates the impact of Wal-Mart market entry in the county and the outlying regions: the research is checking the endogeneity by entry decision of Wal-Mart in more developed regions; spatial analysis is applied and estimates the impact of Wal Mart entry on the region. The results show a net growth of employment and moderate increase of companies in the retail sector.

Addison et al., (2009) examined the impact of the minimum wage on the revenues and employment in selected sectors of retail trade during the time interval of 1990-2005, while employment data is used on the regional level. They focused on subsectors that can be characterized by an extremely low wage. The results show a positive effect on employment. Babecký et al., (2010) evaluates the importance of structural 
factors and institutions by explaining common models and the main differences in the recent expansion of employment services in OECD countries. He emphasises, that GDP per capita, size of the government sector and the extent of urbanization are positively connected with labour market share. The legal background, institutions and regulations about the markets resulted in more coordinated wage system. Schivardi \& Viviano, (2011) focused on the reform of the Italian retail sector in 1998, dealing with the market entry of big stores. They assumed that entry barriers are connected with higher profit margins and lower productivity of the existing firms. The market liberalization has a positive impact on the investment in information communication Technologies. It increases employment and lowers labour costs in big stores. In regions with strict regulations, lower productivity combined with higher profit margins results in higher consumer price. One of the challenges that theoreticians have to face is the change forecasted in the categorization of retail outlets. The increasing number of shopping centres that gain sudden and unexpected success as new retail format enable retailers to keep up with market trends and forecast consumer preferences. The reason why shopping centres are successful is the maximum utilization of sales premises, that can ensure increased productivity and the number of customers (Križan et al., 2015).

Shopping centres have become one of the key players of retail sector transformation in urban areas that influence the development of the region. The research results detected statistically significant values in the case of both hypotheses, so it was possible to reject Hypothesis 0 in favour of the alternative hypothesis. The hypothesis I shows a correlation between the recorded number of employees in retail and the regional GDP per capita (adjusted to price index). The increasing number of shopping centres increases the employment facilities in the regions of Slovakia, as well as the GDP per capita. It results in economic growth while increasing consumptions reflects increasing living standards as well. Hypothesis II shows the correlation between the share of employment in the retail sector and regional GDP per capita (adjusted to price index). The increase in employment in the retail sector will result in a decrease in employment in other sectors and will show declining GDP per capita. Not only the tertiary but the secondary and primary sector as well need further development.

The analysis of macroeconomic correlation detected the direct relationship between the number of employees in the retail sector and the regional GDP. The regional players (city offices, regional offices) should be supported to employ regional residents in the newly opened retail chains. They should also support the education and training of local people to be employed in retail chains of the region. This is providing a possibility to employ the qualified and trained workforce in the appropriate positions.

Funding. Scientific Paper was elaborated within the framework of the projects KEGA 001UCM4/2016, KEGA 035PU-4/2016 and VEGA 1/0139/16.

\section{References}

Addison, J. T., Blackburn, M. L., and Cotti, C. D. (2009), Do minimum wages raise employment? Evidence from the US retailtrade sector. In Labour Economics, Vol. 16, No. 4, pp. 397-408

Anyakoha, C. (2018), "Achieving sustainable development in Nigeria via innovative education. The role of business education. In Acta Oeconomica Universitatis Selye, Vol. 7, No. 1, pp. 7-20

Bačík, R., Štefko, R., and Gburová, J. (2014), Marketing pricing strategy as part of competitive advantage retailers. In Editorial Board, Vol. 9, No. 4, p. 602

Babecký, J., Du Caju, P., Kosma, T., Lawless, M., Messina, J., and Rõõm, T. (2010), Nižšia nominálna a reálna mzdová rigidita: výsledky prieskumu od európskych firiem. In Scandinavian Journal of Economics, Vol. 112, No. 4, pp. 884-910

Benešová, D.; Kubičková, V.; Michálková, A.; and Krošláková, M. (2018), Innovation activities of gazelles in business services as a factor of sustainable growth in the Slovak Republic, In Entrepreneurship and Sustainability Issues, Vol. 5, No. 3, pp. 452-466

Bilková, K., and Križan, F. (2013), Koncentrácia podnikatel'ských subjektov v maloobchode v slovenských mestách. In Geographia Cassoviensis, Vol. 7, No. 1, pp. 31-44

Bobáková, V., and Hečková, J. (2007), The competitive abilities analysis of processing industry of the Slovak republic In Politická ekonomie, Vol. 55, No. 4, pp. 490-507 
Brecka, S., Koraus, A. (2016), Innovation and innovation management in the tourism industry in the context of globalization. Globalization and its socio-economic consequences, In 16 th International scientific conference proceedings, PTS I-V

Buček, M., Rehák, Š., and Tvrdoň, J. (2010). Regionálna ekonómia a politika. lura Edition, Bratislava, p. 269

De Wachter, S., Harris, RD, and Tzavalis, E. (2007), Testy koreňových dátových jednotiek panelu: Úloha sériovej korelácie a časového rozmeru. In Časopis štatistického plánovania a dedukcie, Vol. 137, No. 1, pp. 230-244

Gavurova, B.; Soltes, M.; and Kovac, V. (2017), Application of cluster analysis in process of competitiveness modelling of Slovak republic regions. In Transformations in Business \& Economics, Vol. 16, No. 3, pp. 129-147

Gburová, J. and Marchevská, M. (2016), Marketingová komunikácia v maloobchode. Bookman, p. 89

Grewal, D., Bart, Y., Spann, M., and Zubcsek, P. P. (2016), Mobile advertising: a framework and research agenda. In Journal of Interactive Marketing, Vol. 34, pp. 3-14

Gródek-Szostak, Z.; and Nesterak, J. (2017), Trade missions as the instrument for supporting international technologica cooperation of enterprises - case study of Poland, Slovakia and Czech republic. In Acta Oeconomica Universitatis Selye, Vol. 6, No. 2, pp. $57-68$

Hadad, S., and Cantaragiu, R. (2017), Corporate social entrepreneurship versus social intrapreneurship: same idea, different trajectories? In Management \& marketing-challenges for the knowledge society, Vol.12, No. 2, pp. 252-276

Hatrák, M. (2007), Ekonometria. Bratislava: Iura Edition, p. 504

Hicks, M. J. and Wilburn, K. L. (2001), The regional impact of Wal-Mart entrance: A panel study of the retail trade sector in West Virginia. In The Review of Regional Studies, Vol. 31, No. 3, p. 305

Jankowiak, AH. (2018), Cluster policy models in the Visegrad group countries - a comparative study. In Transformations in Business \& Economics, Vol. 17, No. 2A, pp. 447-465

Kotulič, R. Huttmanová, E., Vozárová Kravčáková, I. and Nagy J., M. (2017), The Structural of The Sectors of Slovak Economy and Employment in Times of Global Change and The Subsequent Development. In Procedia Economics and Finance. Vol. 23, pp. 1590-1595

Kita, P., Kita, P., Kupkovičová, P., and Janska, M. (2017), The infuence of economic geography on supermarket concentration. In AD ALTA-Journal of Interdisciplinary Research, Vol. 7, No. 1, pp. 68-72

Korcsmáros, E. (2018), Factors affecting the development of SMEs (example from Slovakia based on primary research in Nitra region). In Acta Oeconomica Universitatis Selye, Vol. 7, No. 1, pp. 70-78

Kusa, A., Zazikova, Z. (2017), Influence of the social networking website snapchat on the generation Z. In European Journal of Science and Theology, Vol. 12, No. 5, pp. 145-154

Križan, F., Barlík, P., and Bilková, K. (2017), Nákupné správanie mladých spotrebitel'ov: Ako často nakupujú? (Prípadová štúdia z Bratislavy). In Geografia, Vol. 24, No. 2, pp. 40-43

Križan, F., Bilková, K., Kita, P., Kunc, J., and Barlík, P. (2015), Nákupné centrá v Bratislave a atribúty ovplyvňujúce preferencie spotrebitelov. In Geografický časopis, Vol. 67, No. 4, pp. 341-357

Lábaj, M. (2013), Development of the Slovak Economy in 2008 and 2009 from the Perspective of Input-output Analysis. In Ekonomický časopis, Vol. 61, No. 10, pp. 994-1010

Lagakos, D. (2016), Explaining cross-country productivity differences in retail trade. In Journal of Political Economy, Vol. 124, No. 2, pp. $579-620$

Lauko, V., Križan, F., and Tolmáči, L. (2008), Potravinársky maloobchod v Slovenskej republike: rurálne prostredie, čas a miesto nákupu. In Acta Facultatis Rerum Naturalium Universitatis Comenianae, Geographica, Vol. 51, pp. 41-55

Lesáková, D., and Daňo, F. (2016), Food Shopping Behaviour in Older Consumers' Segment. Central and eastern europe in the changing business environment, $\mathrm{p}$. 270

Lieskovská, V., Bilohuščinová, D. and Megyesiová, S. (2013), The influence of marketing communication on the merchantability of food products in the Slovak Republic. 7th International Days of Statistics and Economics, pp. 778-786

Lynch, P.; Power, J.; Hickey, R.; and Messervey, T. (2017), Business model strategies: Flexibility trade in emerging low voltage distribution networks, In Entrepreneurship and Sustainability Issues, Vol. 4, No. 3, pp. 380-391

Majerova, J., Krizanova, A., and Zvarikova, K. (2013), Social media marketing and possibilities of quantifying its effectiveness in the process of brand value building and managing. Financial management of firms and financial institutions: 9th International scientific conference proceedings, pts I-III, pp. 476-485

Mazurek, S. (2018), Strategic orientations of the network business models. In Transformations in Business \& Economics, Vol.

17, No. 2A, pp. 410-425

Mendelova, D., Zauskova, A. (2015), Innovation in the Slovak advertising environment. Communication today, Vol. 6, No. 1, pp. 38

Mészáros, M. (2018), "Employing" of self-employed persons. In Central European Journal of Labour Law and Personnel Management, Vol. 1, No. 1

Moravcikova, D., Krizanova, A., Kliestikova, J., Rypakova, M. (2017), Green marketing as the source of the competitive advantage of the business. In Sustainability (Switzerland), Vol. 9, No. 12, 2218, p. 13

Musová, Z., Huliaková, Z. and Musa, H. (2016), Consumers' perception of the brand in the cause-related marketing. Marketing identity: brands we love, PT II, pp. 219-230

Nemcova, E. (2004), The function of clusters in the development of region. In Ekonomicky casopis, Vol. 52, No. 6, pp. 739-754 
Otter, C., and Halasi, D. (2018), Payment discipline of business in the EU countries. In AD ALTA-Journal of Interdisciplinary Research, Vol. 8, No. 1, pp. 90-94

Peracek, T., Kocisova, L., Mucha, B. (2017), Importance of the e-government act and its impact on the management and economy of the enterprise in the Slovakia. In Management and economics in manufacturing, pp. 90-96

Samašonok, K.; Išoraitè, M.; and Leškienè-Hussey, B. (2016), The internet entrepreneurship: opportunities and problems, In Entrepreneurship and Sustainability Issues, Vol. 3, No. 4, pp. 329-349

Seres Huszárik, E. and Dobai Korcsmáros, E. (2013), The main innovator of the retail market. In Acta Oeconomica Universitatis Selye, Vol. 2, No. 2, pp. 195-204

Schivardi, F., and Viviano, E. (2011), Entry barriers in retail trade. In The Economic Journal, Vol. 121, No. 551, pp. 145-170

Spilková, J. (2016), Alternativní potravinové sitě: Česká cesta. Charles University in Prague, Karolinum Press.

Slach, O., Koutský, J., Novotný, J., and Zenka, J. (2013), Creative industries in the Czech republic: a spatial perspective. In E \& M Ekonomie a Management, Vol. 16, No. 4, pp. 14-29

Statistical Office of the Slovak Republic. (2017), Demography and Social statistics. Available at http://www.statistics.sk Straková, J., Pártlová, P. and Váchal, J. (2017), Business management in new global economy. In Acta Oeconomica Universitatis Selye, Vol. 6, No. 1, pp. $155-166$

Strazovska, L., Duris, M. (2017), Online marketing trends for 2017, In Hradec Economic Days, vol 7 (1), pp. 838-844

Streimikiene, D. (2014), The impact of research and development for business innovations in Lithuania. In Amfiteatru Economic Vol. 16, No. 37 , pp. $965-979$

Supeková, S. (2015), Aspects of green marketing: The current situation in the selected companies in the Slovak republic. In Current Issues of Science and Research in the Global World - Proceedings of the International Conference on Current Issues of Science and Research in the Global World, pp. 133-141

Štefko, R., Bacik, R., and Gburova, J. (2015), Impact of the selected economic factors and advertising on Slovak consumer buying behavior. In Interdisciplinary Behavior and Social Sciences: Proceedings of the 3rd International Congress on Interdisciplinary Behavior and Social Science 2014 (ICIBSoS 2014), 1-2 November 2014, Bali, Indonesia. (p. 151). CRC Press.

Tvaronavičienè, M., Tarkhanova, E., and Durglishvili, N. (2018), Sustainable economic growth and innovative development of educational systems. In Journal of International Studies, Vol. 11, No. 1, pp. 248-256

Tvrdoň, O., Presová, R., and Pribyl, M. (2015), Economic-legal aspects of business assets definition and its effectiveness analysis. In Acta Universitatis Agriculturae et Silviculturae Mendelianae Brunensis, Vol. 52, No. 6, pp. 189-210

Л. Мура, д.е.н., доцент, Пан-Європейський університет у Братиславі (Словаччина);

М. Марчевська, д.е.н., Прешовський університет (Словаччина);

М. Дубравська, д.е.н., Прешовський університет (Словаччина).

Словацький роздрібний бізнес: панельна регресійна модель

На функціонування бізнес-сектору безпосередньо впливає рівень соціально-економічного розвитку міста, регіону та країни. Особливо на роздрібну торгівлю впливає споживання домогосподарств, що безпосередньо пов'язано з рівнем соціально-економічного розвитку регіону. У рамках даної статті авторами проаналізовано підходи до розуміння сутності роздрібної торгівлі, а також ії вплив на розвиток регіону на прикладі Словаччини. Дослідження базується на аналізі основних макроекономічних показників Словаччини. На основі результатів аналізу наукової літератури авторами було виокремлено ключові змінні роздрібної торгівлі та проведено їх оцінку. Метою дослідження є перевірка гіпотези про статистичну значимість взаємозв'язку між зареєстрованою кількістю працівників у секторі роздрібної торгівлі та ії впливом на регіональний розвиток з урахуванням ключового макроекономічного показника - регіонального ВВПП. Об'єкт дослідження - сектор роздрібної торгівлі Словаччини. У ході аналізу використовувались основні макроекономічні індикатори розвитку Словаччини. у ході дослідження перевіряється дві гіпотези в залежності від змінних: наявність статистично значимих зв'язків між зареєстрованою кількістю працівників у роздрібній торгівлі, питомою вагою зареєстрованих працівників у роздрібній торгівлі у загальній зайнятості та регіональним ВВП на душу населення (з урахуванням індексу цін). Для перевірки гіпотез були використані річні дані за 2000-2010 рр. У якості основних змінних було обрано: зареєстрована кількість працівників у роздрібній торгівлі; питома вага зайнятих у роздрібній торгівлі у загальній кількості працевлаштованих в регіоні. Авторами було застосовано статистичне програмне забезпечення Stata, розраховано стандартне відхилення (t-statistics, p-values) та використано такі методи дослідження: метод Дрисколл-Край та метод найменших квадратів. Результати дослідження свідчать про наявність кореляції та прямий взаємозв'язок між кількістю працівників у секторі роздрібної торгівлі та регіональним ВВП.

Ключові слова: валовий внутрішній продукт; регіональний розвиток, регресійна модель, роздрібна торгівля.

Manuscript received: 22.10 .2018

(C) The author(s) 2018. This article is published with open access at Sumy State University. 